\title{
Synthesis of carbo- and heterobiaryls by intermolecular radical addition of aryl bromides onto aromatic solvents
}

\author{
Araceli Núñez, Aránzazu Sánchez, Carolina Burgos and Julio Alvarez-Builla* \\ Departamento de Química Orgánica. Universidad de Alcalá, 28871 Alcalá de Henares, Madrid, Spain
}

Received 25 February 2004; revised 15 April 2004; accepted 7 May 2004

Available online 9 June 2004

Abstract-Tris(trimethylsilyl)silane (TTMSS) and azabisisobutyronitrile (AIBN) promoted the intermolecular arylation of aryl and heteroaryl bromides onto aromatic solvents under thermal conditions via a radical pathway.

(C) 2004 Elsevier Ltd. All rights reserved.

\section{Introduction}

Biaryls $\left(\mathrm{Ar}^{1}-\mathrm{Ar}^{2}\right)$ and related systems, such as heterobiaryls and arylheterocyclic compounds have found numerous applications in several fields: as advanced materials, biologically active molecules, chelating agents or metal ligands. ${ }^{1-3}$ Consequently, a wide variety of synthetic methods have been developed for their preparation, with palladium cross-coupling reactions currently being the most popular choice. ${ }^{1,4}$ Additional methods reported for the preparation of biaryls include some examples involving arylation of arenes through radical mechanisms. Intramolecular radical additions, of aryl radicals to benzene ${ }^{5}$ or heterocyclic rings, ${ }^{6}$ under reductive conditions, followed by rearomatisation, have been reported. In this context, intramolecular arylations, by ipso substitution of suitable sulfonyl, ${ }^{7}$ phosphinate ${ }^{8}$ silyl $^{9}$ or benzylic ether ${ }^{10}$ derivatives, also under reductive conditions, have been widely reported for the preparation of both biaryls and arylheterocyclic derivatives. On the other hand, the intermolecular version of the radical arylation has been scarcely explored. At the start of the present project, only radical approaches based on photochemical arylation of arenes, among other oxidative conditions, have been described. ${ }^{11}$ Our group recently reported a simple method for the preparation of aryl compounds, ${ }^{12}$ based on thermal intermolecular radical addition of aryl or heteroaryl radicals onto benzene (Scheme 1). The process takes place under reductive conditions, using the corresponding aryl bromides as starting material and AIBN/TTMSS (azobis-isobutyronitrile/tris(trimethylsilyl)silane) as initiator for the radical

Keywords: Aryl bromides; Arylation; Biaryls; Radicals and radical reaction; Tris(trimethylsilyl)silane (TTMSS).

* Corresponding author. Tel.: +34-91-885-4606; fax: +34-91-885-4686; e-mail address: julio.alvarez@uah.es

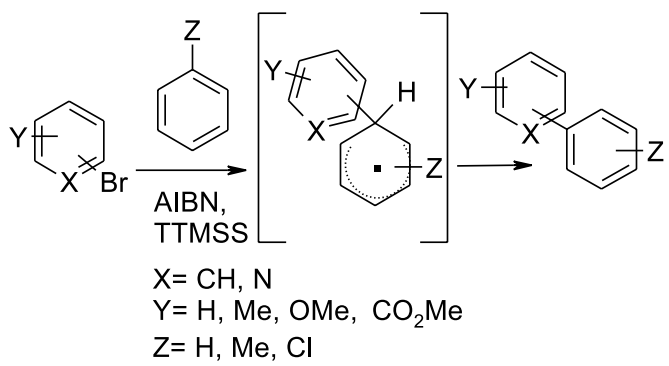

Scheme 1.

process. The intermolecular radical addition of orthofunctionalized aryl iodides to benzene has recently been applied by Crich and Sannigrahi in an elegant approach to functionalised tetrahydrobenzofuranes. ${ }^{13}$

In this paper, the results on the intermolecular addition of aryl (and heteroaryl) radicals onto arenes and heteroarenes are described. During the study, scope and limitations of the process were evaluated, by varying the radical acceptor (usually the solvent) and the aryl radical donor.

\section{Results and discussion}

\subsection{Variations on the radical acceptor}

In a preceding communication ${ }^{12}$ we reported phenylation of 2-bromopyridine 1a (Scheme 2, $\mathrm{Z}=\mathrm{H}$; Table 1, entry 1). The best results were obtained by slow addition $(8 \mathrm{~h})$ of a solution of TTMSS (2 equiv.), AIBN (2 equiv.) and 2-bromopyridine ( 1 equiv.) in $5 \mathrm{~mL}$ of benzene, into an additional $10 \mathrm{~mL}$ of benzene (Method A), to supply 2-phenylpyridine 2a in $41 \%$ yield. Similar results were obtained from 3-bromopyridine $\mathbf{1 b}$, which gave 


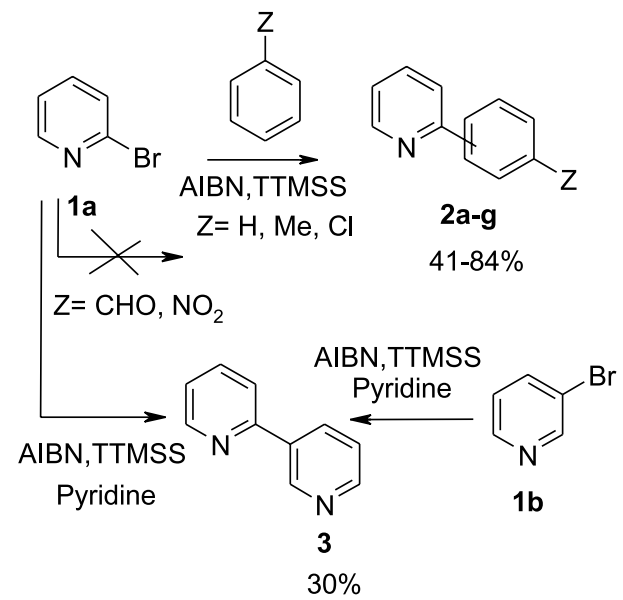

Scheme 2. 3-phenylpyridine $\mathbf{2 b}$ in $74 \%$ yield (Table 1, entry 2). Attempts to extend the scope of the process were carried out using toluene (Scheme 2, Z=Me; Table 1 , entry 3 ) and chlorobenzene (Scheme 2, $\mathrm{Z}=\mathrm{Cl}$; Table 1, entry 4) as aromatic solvents. In these cases, the best results were obtained using chlorobenzene, an electron-poor substrate, which produced a mixture of the 2-phenylpyridines (13:0:1 of the $o / \mathrm{m} / \mathrm{p}$ isomers) with an overall yield of $84 \%$. The use of toluene led to a mixture of the corresponding 2-tolylpyridines (2:1:1 of the o/m/p isomers) in $61 \%$ overall yield. As the best results were obtained using chlorobenzene, other electron-deficient solvents were also tested, such as benzaldehyde (Scheme 2, Z=CHO; Table 1, entry 5) or nitrobenzene (Scheme 2, $\mathrm{Z}=\mathrm{NO}_{2}$; Table 1, entry 6): but no arylated products were detected.

Pyridine, another electron-deficient substrate was also tested. Thus, when the process was carried out using 2-bromopyridine 1a as a source of the 2-pyridyl radical, and pyridine as the solvent, 2,3'-bipyridine $\mathbf{3}$, was isolated, in a

Table 1. Variations of the (radical acceptor) solvent

\begin{tabular}{|c|c|c|c|c|c|c|}
\hline Entry & Starting material & Solvent & Biaryl comp. & Ratio & Yield $(\%)^{\mathrm{a}}$ & Method \\
\hline 1 & 1a & $\mathrm{Ph}-\mathrm{H}$ & & - & 41 & A \\
\hline 2 & $1 \mathrm{~b}$ & $\mathrm{Ph}-\mathrm{H}$ & & - & 74 & A \\
\hline 3 & 1a & $\mathrm{Ph}-\mathrm{Me}$ & & $\begin{array}{l}o / \mathrm{m} / p \\
2: 1: 1\end{array}$ & 61 & A \\
\hline 4 & 1a & $\mathrm{Ph}-\mathrm{Cl}$ & & $\begin{array}{l}o / \mathrm{m} / \mathrm{p} \\
13: 0: 1\end{array}$ & 84 & A \\
\hline 5 & 1a & $\mathrm{Ph}-\mathrm{CHO}$ & $21, \mathrm{~g}$ & - & - & A \\
\hline 6 & $1 \mathrm{a}$ & $\mathrm{Ph}-\mathrm{NO}_{2}$ & - & - & - & A \\
\hline 7 & 1a & Pyr & & - & 30 & A \\
\hline 8 & $1 \mathrm{~b}$ & Pyr & 3 & - & 30 & A \\
\hline 9 & 1a & $\mathrm{C}_{10} \mathrm{H}_{8}$ & & $\begin{array}{l}\alpha: \beta \\
3: 1\end{array}$ & 61 & B \\
\hline 10 & $1 \mathrm{~b}$ & $\mathrm{C}_{10} \mathrm{H}_{8}$ & & $\begin{array}{l}\alpha: \beta \\
5: 1\end{array}$ & 50 & B \\
\hline
\end{tabular}

${ }^{a}$ Yields refer to isolated pure product. All the compounds were identified by spectroscopic and literature data. Method A: TTMSS (2 equiv.), AIBN (2 equiv.), the corresponding pyridyl bromide $\mathbf{1}\left(1\right.$ equiv.) in the solvent $(5 \mathrm{~mL})$ added into an additional $10 \mathrm{~mL}$ of the corresponding solvent during $8 \mathrm{~h}, 80^{\circ} \mathrm{C}, 24 \mathrm{~h}$. Method B: TTMSS ( 2 equiv.), AIBN (2 equiv.), the corresponding pyridyl bromide 1 in MeCN $\left(5 \mathrm{~mL}\right.$ ) added over naphthalene $\left(55\right.$ equiv.) during $4 \mathrm{~h}, 80^{\circ} \mathrm{C}, 24 \mathrm{~h}$. 


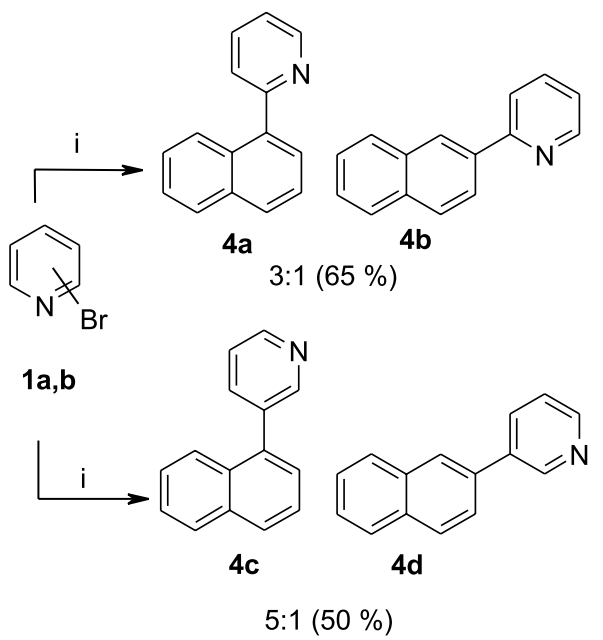

i) Naphthalene, TTMSS, AIBN

Scheme 3.

$30 \%$ yield (Scheme 2; Table 1, entry 7). Surprisingly, the same process using 3-bromopyridine $\mathbf{1 b}$ as the starting material, also yielded 2,3'-bipyridine 3, again in $30 \%$ yield, and only traces of the alternative isomeric compound (Scheme 2; Table 1, entry 8). In general, one would expect that the regioselectivity of the process mainly depends on the electrophilicity or nucleophilicity of both, radical and acceptor, as well as on polar effects and orbital control. As far as the character of attacking radicals is concerned, it is now recognized that heteroaryl species with a carbon radical adjacent to the heteroatom behave as electrophiles, with the electrophilicity interpreted in terms of the inductive effect of the ring heteroatom. ${ }^{11 \mathrm{a}, \mathrm{b}}$ In all examples discussed, the 2-pyridyl radical would act as an electrophile, thus attacking either substituted benzenes or pyridine when they are both acceptor and solvent. Almost all substituents stabilize radicals, and so, substituted benzenes, including toluene and chlorobenzene, usually react faster than benzene itself. Furthermore, most substituted benzenes show some preference for ortho/para attack, because attack at these sites gives the more stable intermediates. ${ }^{14}$ Moreover, in the case of chlorobenzene, the mesomeric $\pi$-donor character of the chloro-substituent must be taken into consideration. In a

Table 2. Variations on the radical

\begin{tabular}{|c|c|c|c|c|c|}
\hline Entry & Starting material & Biaryl compound & Ratio $\alpha: \beta: \gamma$ & Yield $(\%)^{\mathrm{a}}$ & Method \\
\hline 1 & $5 \mathbf{a}$ & & - & 51 & A \\
\hline 2 & $5 \mathbf{b}$ & & - & 50 & A \\
\hline 3 & $5 c$ & & - & 52 & A \\
\hline 4 & $5 a$ & & - & - & A \\
\hline 5 & $5 \mathbf{a}$ & $\begin{array}{l}2 \mathrm{e}, / \\
2 \mathrm{e}, 7\end{array}$ & $4: 1: 0$ & 10 & $\mathrm{C}$ \\
\hline 6 & $5 b$ & & $4: 1: 1$ & 30 & A \\
\hline 7 & $5 b$ & $\begin{array}{l}8 a-c \\
8 a-c\end{array}$ & $10: 1: 4$ & 72 & $\mathrm{C}$ \\
\hline 8 & $5 c$ & & $2: 1: 0$ & 15 & A \\
\hline 9 & $5 c$ & $\begin{array}{c}9 \mathbf{a}, \mathbf{b} \\
9 \mathbf{a}-\mathbf{c}\end{array}$ & $2: 1: 0.1$ & 20 & $\mathrm{C}$ \\
\hline
\end{tabular}

a Yields refer to isolated pure product. All the compounds were identified by spectroscopic and literature data. Method A: TTMSS ( 2 equiv.), AIBN ( 2 equiv.), the corresponding aryl bromide 5 ( 1 equiv.) in the solvent $(5 \mathrm{~mL})$ added into an additional $10 \mathrm{~mL}$ of solvent during $8 \mathrm{~h}, 80^{\circ} \mathrm{C}, 24 \mathrm{~h}$. Method $\mathrm{C}$ : TTMSS ( 2 equiv.), AIBN ( 2 equiv.), the corresponding pyridyl bromide 5 (1 equiv.) in pyridine $(5 \mathrm{~mL})$ added over additional $10 \mathrm{~mL}$ of pyridine and $2.5 \mathrm{~mL}$ of acetic acid during $8 \mathrm{~h}, 80^{\circ} \mathrm{C}, 24 \mathrm{~h}$. 
similar way, when the solvent is pyridine, the 2-pyridyl radical would behave as an electrophile, thus attacking at the 3-position, a situation in agreement with other photochemical arylations described previously. ${ }^{11 a}$ In contrast, the 3 -pyridyl radical, which is comparatively nucleophilic, would attack preferentially at the 2-position of the pyridine acceptor.

Several attempts were undertaken to make the radical more $\pi$-deficient (e.g., using 2-bromopyridine- $N$-oxide instead of 2-bromopyridine) or to increase the electrophilicity of the solvent (e.g., using thiophene instead of pyridine). However, these approaches did not generate any satisfactory results.

Other aromatic solvents were also tested. Reaction of the 2-pyridyl radical, obtained from 2-bromopyridine 1a on naphthalene, using a modified experimental method (Method B) (see Table 1 and Section 4) produced a 3:1 mixture of $\alpha / \beta$ naphthyl derivatives $\mathbf{4 a}, \mathbf{b}$ in $61 \%$ yield (Scheme 3; Table 1, entry 9). Similarly, 3-bromopyridine 1b, produced a 5:1 mixture of $\alpha / \beta 3$-(naphthyl)pyridines $\mathbf{4 c , d}$ (Scheme 3; Table 1, entry 10). The regioselectivity of the radical attack is clearly as one would expect, considering orbital control, because of the symmetry of the system and in agreement with the regioselectivity reported for other radical arylations. ${ }^{14,15}$

\subsection{Variations on the aryl radical}

It is an axiom in radical chemistry that the $\pi$-system in an aryl radical should have little or no effect on its reactivity, since the unpaired electron would be placed on the $\sigma$-skeleton. ${ }^{16,17}$ On this assumption, additional experiments were carried out using 4-methylphenyl, 4-methoxyphenyl, and 4-methoxycarbonylphenylbromides $\mathbf{5 a}-\mathbf{c}$ as sources of aryl radicals. In a previous communication ${ }^{12}$ we reported these arylations using benzene as solvent, which yielded compounds $\mathbf{6 a}-\mathbf{c}(50-52 \%)$ essentially yielding the same results for both, heterocyclic and carbocyclic radicals. The experimental results are summarized in Table 2 (Entries $1-3$ ) and in Section 4. The same process, but using pyridine as solvent, is outlined in Scheme 4 and Table 2. The slow addition ( $8 \mathrm{~h}$ ) of a solution of TTMSS ( 2 equiv.), AIBN ( 2 equiv.) and 1-bromo-4-methyl benzene 5a (1 equiv.) in pyridine to an additional $10 \mathrm{~mL}$ of pyridine at $80^{\circ} \mathrm{C}$, with

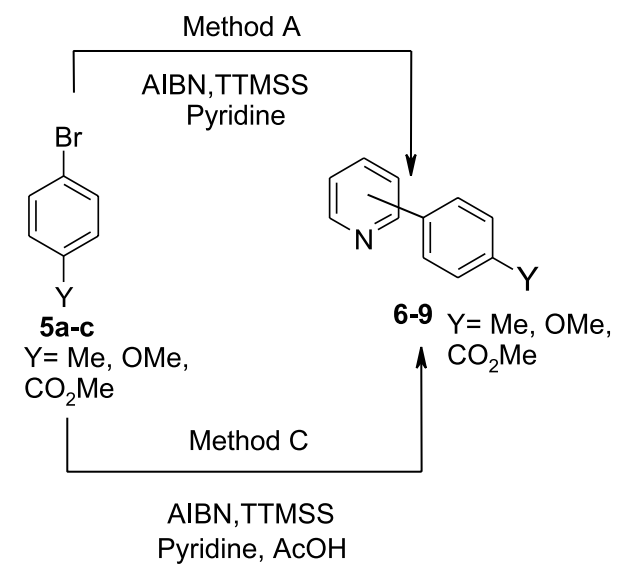

Scheme 4. the mixture kept at $80{ }^{\circ} \mathrm{C}$ for a further $16 \mathrm{~h}$, did not generate any detectable biaryl (Table 2, entry 4). When the same conditions were applied to 1-bromo-4-methoxy-benzene $\mathbf{5 b}$ as the starting material, biaryls $\mathbf{8 a}-\mathbf{c}$ were isolated in $30 \%$ yield (4:1:1 of the $\alpha: \beta: \gamma$ isomers) (Table 2 , entry 6$)$. The same process, when applied from 4-bromo benzoic acid methyl ester 5c, yielded 15\% of biaryls $\mathbf{9 a}, \mathbf{b}$ (2:1:0 of the $\alpha: \beta: \gamma$ isomers) (Table 2, entry 8). The experimental results seem to suggest that all radical species used in this particular type of reaction behave as relatively nucleophilic, with the ring substituents, however, exerting some effect on the reactivity of such radicals. The lack of reactivity for compound 5a and the higher percentage of $\alpha$-substitution on pyridine in the other cases could, tentatively, be explained by considering the following two classes of factors:

(a) A relatively nucleophilic radical has a higher energy SOMO and will react faster with molecules having a lowenergy LUMO. ${ }^{14,18,19}$

(b) For unprotonated pyridines, the reactivity and selectivity on the homolytic phenylation appears to be mainly governed by the stability of the intermediate radical adduct $\mathbf{1 0}^{20}$ (Scheme 5), with regioselectivity being $\alpha>\beta$ for both the more and the less nucleophilic radical (i.e., radicals derived from $\mathbf{5 b}$ and $\mathbf{5 c}$, respectively). Since there is no radical $\pi$-stabilizing effect by aryl substituents, a relatively weak inductive effect could be exerted by the relatively $\pi$-excessive or $\pi$-deficient aryl substrate (intermediate $\mathbf{1 0} \boldsymbol{\alpha}, \boldsymbol{\beta}$, where $\mathrm{Y}=\mathrm{OMe}$ or $\mathrm{CO}_{2} \mathrm{Me}$, respectively), ${ }^{19}$ whereas the absence of such effect in $\mathbf{5 a}$ should prevent the progress of the reaction.

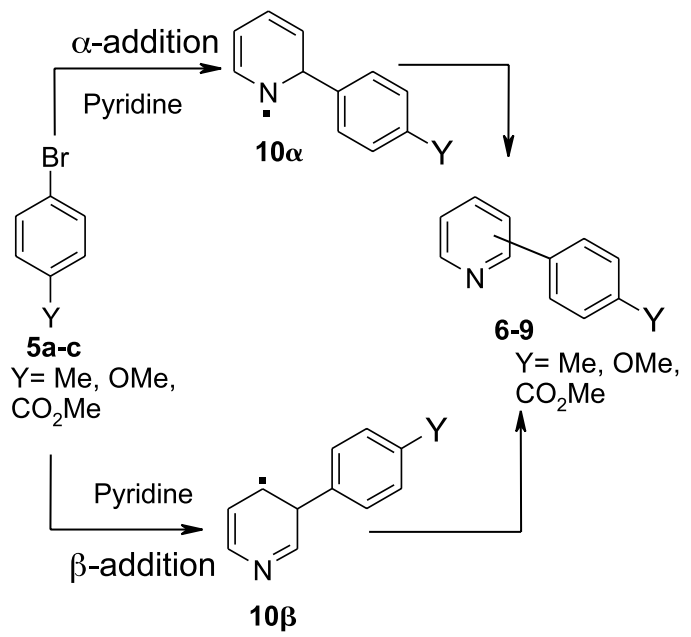

Scheme 5 .

Presumably, the radical arylation on protonated heteroaromatic bases will be more important, where the dominant SOMO/LUMO interaction may well be stronger. So in the case of unsubstituted pyridinium cation, reaction at the $\alpha$ - and at the $\gamma$-positions is predicted according to theory. ${ }^{19,20}$ Bearing these factors in mind, and in accordance with the work of Minisci ${ }^{20-22}$ and Togo, ${ }^{23,24}$ the reaction was performed in an acidic medium. Thus, in protonated pyridines, in which polarity is strongly increased, the polar effect would play a significant role in determining both 
reactivity and regioselectivity (Table 2). ${ }^{20}$ Protonated heteroarenes are $\pi$-deficient substrates, which react with nucleophilic radicals with high regioselectivity, and the rate of radical addition correlated with nucleophilicity of the attacking radical (derived from $\mathbf{5 a}$ and $\mathbf{5 b}$, entries 5 and 7 , respectively), whereas the reaction with the less nucleophilic radical (derived from 5c, entry 9) is scarcely affected with regard to reactivity and regioselectivity.

\section{Conclusion}

As a conclusion, a simple method of synthesis of biaryl compounds has been developed, based on the intermolecular radical addition of aryl or heteroaryl radicals onto an aromatic solvent. The method is very efficient when the aromatic solvent is benzene, but in general, occurs in low yields on other arenes. Experimental results seem to suggest that most aryl radicals, are nucleophilic to some extent, with aryl substituents modulating the reactivity through their electronic effect on the $\pi$-aryl system.

\section{Experimental}

\subsection{General}

All experiments were carried out under dry argon atmosphere. Toluene and benzene were distilled from sodium under dry argon. Chlorobenzene was distilled from calcium chloride, under dry argon. Pyridine was distilled from potassium hydroxide pellets under dry argon. Acetonitrile was distilled from phosphorus pentoxide under dry argon. Naphthalene was crystallized from ethanol. All chemicals were purchased from Aldrich Chemical company and were used without purification. ${ }^{1} \mathrm{H}$ and ${ }^{13} \mathrm{C}$ were recorded on a Varian UNITY $300 \mathrm{MHz}$ or a VARIAN UNITY PLUS $500 \mathrm{MHz}$ spectrometers. Mass spectra were recorded on a VG AutoSec (Micromass Instrument).

\subsection{General procedure. Method A}

A solution of TTMSS (498 mg, $2 \mathrm{mmol}$ ), AIBN (328 mg, $2 \mathrm{mmol}$ ), and the corresponding bromide $\mathbf{1 a}, \mathbf{b}$ or $\mathbf{5 a}-\mathbf{c}$ ( $1 \mathrm{mmol}$ ) in $5 \mathrm{~mL}$ of the suitable solvent, was dropwise added with a syringe pump along $8 \mathrm{~h}$, to $10 \mathrm{~mL}$ of the same solvent, stirred at $80^{\circ} \mathrm{C}$ (bath temperature). Stirring was maintained at the same temperature for $24 \mathrm{~h}$, and full consumption of starting material was observed (TLC analysis). The pale yellow solution was concentrated in vacuo, providing a crude mixture that was purified using flash chromatography to yield the corresponding biaryl compound.

\subsection{Method B}

A solution of TTMSS (498 mg, $2 \mathrm{mmol}$ ), AIBN (328 mg, $2 \mathrm{mmol}$ ) and the corresponding bromide $\mathbf{1 a}, \mathbf{b}(1 \mathrm{mmol}$, $158 \mathrm{mg}$ ) in $5 \mathrm{~mL}$ of $\mathrm{MeCN}$, was dropwise added with a syringe pump over $4 \mathrm{~h}$, to $7 \mathrm{~g}(55 \mathrm{mmol})$ of naphthalene, stirred at $80^{\circ} \mathrm{C}$ (bath temperature). Stirring was maintained at the same temperature for $24 \mathrm{~h}$, and full consumption of $\mathbf{1}$ was observed (TLC analysis). The solution was concentrated, providing a crude mixture, which was separated by flash chromatography (silicagel, hexanes/ethyl acetate (80:20)), yielding the pure compounds.

\subsection{Method C}

A solution of TTMSS (498 mg, $2 \mathrm{mmol}$ ), AIBN (328 mg, $2 \mathrm{mmol})$, and the corresponding bromide $\mathbf{5 a}-\mathbf{c}(1 \mathrm{mmol})$ in $5 \mathrm{~mL}$ of pyridine, was dropwise added with a syringe pump over $8 \mathrm{~h}$, to $10 \mathrm{~mL}$ of pyridine and $5 \mathrm{~mL}$ of acetic acid, stirred at $80^{\circ} \mathrm{C}$ (bath temperature). Stirring was maintained at the same temperature for $24 \mathrm{~h}$, then the solution was made basic with potassium carbonate and extracted with ethyl acetate. The combined organic phases were dried over $\mathrm{Na}_{2} \mathrm{SO}_{4}$ and evaporated to dryness. The residue was purified using flash chromatography to yield the corresponding compounds 7-9.

\subsection{Preparation of arylpyridines $2 \mathrm{a}-\mathrm{g}$ and bipyridine 3}

4.5.1. 2-Phenylpyridine $2 \mathbf{a}^{\mathbf{2 5}}$ The general procedure (Method A) using 1a (158 mg) as bromide and benzene as solvent gave, after flash chromatography (silicagel, hexanes/ethyl acetate (90/10)), a colorless liquid (63.5 mg, $41 \%$ ). This product was identical to an authentic sample obtained from Aldrich. ${ }^{1} \mathrm{H} \mathrm{NMR}\left(300 \mathrm{MHz}, \mathrm{CDCl}_{3}\right) \delta 8.69$ (td, $1 \mathrm{H}, J=4.7,1.4 \mathrm{~Hz}), 8.01(\mathrm{dd}, 2 \mathrm{H}, J=8.4,1.6 \mathrm{~Hz}), 7.69$ $(\mathrm{m}, 2 \mathrm{H}), 7.45(\mathrm{~m}, 3 \mathrm{H}), 7.19(\mathrm{dd}, 1 \mathrm{H}, J=8.8,4.7 \mathrm{~Hz}) ;{ }^{13} \mathrm{C}$ NMR (75 MHz, $\left.\mathrm{CDCl}_{3}\right) \delta 157.1,149.4,139.2,136.5,128.8$, $128.5,126.7,121.8,120.3$.

4.5.2. 3-Phenylpyridine $\mathbf{2 b} .^{\mathbf{2 5 , 2 6}}$ The general procedure (Method A) using $\mathbf{1 b}$ as bromide (158 $\mathrm{mg}$ ) and benzene as solvent gave, after flash chromatography (silicagel, hexanes/ethyl acetate (80:20)), a colorless liquid (115 mg, $74 \%)$. The product was identical to an authentic sample obtained from Aldrich. ${ }^{1} \mathrm{H} \mathrm{NMR}\left(300 \mathrm{MHz}, \mathrm{CDCl}_{3}\right) \delta 8.83$ (dd, $1 \mathrm{H}, J=2.6,0.9 \mathrm{~Hz}), 8.57$ (dd, $1 \mathrm{H}, J=4.9,1.6 \mathrm{~Hz}), 7.85$ (ddd, $1 \mathrm{H}, J=7.7,2.6,1.6 \mathrm{~Hz}), 7.56(\mathrm{dd}, 2 \mathrm{H}, J=8.2,1.4 \mathrm{~Hz})$, $7.45(\mathrm{~m}, 3 \mathrm{H}), 7.34$ (ddd, $1 \mathrm{H}, J=7.7,4.9,0.9 \mathrm{~Hz}) ;{ }^{13} \mathrm{C} \mathrm{NMR}$ $\left(75 \mathrm{MHz}, \mathrm{CDCl}_{3}\right) \delta 148.3,148.2,137.7,136.4,134.2$, $128.9,127.9,127.0,123.3$.

4.5.3. 2-(2'-Methylphenyl)pyridine $2 c,,^{27,28} 2$-( $\left(3^{\prime}\right.$-methylphenyl)pyridine $2 d^{27,28}$ and $2-\left(4^{\prime}\right.$-methylphenyl)pyridine 2e. ${ }^{11 a, 27,29}$ The general procedure (Method A) using 1a as bromide $(158 \mathrm{mg})$ and toluene as solvent, gave a mixture of products $(o / m / p, 2: 1: 1)$. After separation by flash chromatography (silicagel, dichloromethane/ethyl acetate (100:2.5)), pure compounds $\mathbf{2 c}$, $2 \mathbf{d}$ and $\mathbf{2 e}$ were obtained. Yield $61 \%\left(50.5 \mathrm{mg}\right.$ of $\mathbf{2 c}\left(R_{\mathrm{f}}=0.35\right), 27 \mathrm{mg}$ of $\mathbf{2 d}$ $\left(R_{\mathrm{f}}=0.41\right)$ and $25.5 \mathrm{mg}$ of $\left.2 \mathrm{e}\left(R_{\mathrm{f}}=0.40\right)\right)$. 2c Colorless oil; ${ }^{1} \mathrm{H}$ NMR $\left(500 \mathrm{MHz}, \mathrm{CDCl}_{3}\right) \delta 8.68$ (ddd, $1 \mathrm{H}, J=4.8,1.8$, $1.0 \mathrm{~Hz}), 7.72(\mathrm{dt}, 1 \mathrm{H}, J=7.7,1.8 \mathrm{~Hz}), 7.37(\mathrm{td}, 1 \mathrm{H}, J=7.7$, $1.0 \mathrm{~Hz}), 7.36(\mathrm{~m}, 1 \mathrm{H}), 7.27(\mathrm{~m}, 3 \mathrm{H}), 7.22$ (ddd, $1 \mathrm{H}, J=7.7$, 4.8, $1.0 \mathrm{~Hz}), 2.34(\mathrm{~s}, 3 \mathrm{H})$. 2d Colorless oil; ${ }^{1} \mathrm{H}$ NMR $\left(500 \mathrm{MHz}, \mathrm{CDCl}_{3}\right) \delta 8.68(\mathrm{ddd}, 1 \mathrm{H}, J=4.8,1.5,1.0 \mathrm{~Hz})$, 7.82 (bs, 1H), 7.73 (dt, 1H, $J=8.0,1.5 \mathrm{~Hz}), 7.70(\mathrm{~m}, 2 \mathrm{H})$, $7.34(\mathrm{t}, 1 \mathrm{H}, J=7.6 \mathrm{~Hz}), 7.21(\mathrm{~m}, 1 \mathrm{H}), 7.20$ (ddd, $1 \mathrm{H}, J=8.0$, $4.8,1.9 \mathrm{~Hz}) 2.42(\mathrm{~s}, 3 \mathrm{H})$. 2e Colorless oil; ${ }^{1} \mathrm{H}$ NMR $\left(300 \mathrm{MHz}, \mathrm{CDCl}_{3}\right) \delta 8.67(\mathrm{~d}, 1 \mathrm{H}, J=4.4 \mathrm{~Hz}), 7.86(\mathrm{~d}, 2 \mathrm{H}$, $J=8.1 \mathrm{~Hz}), 7.70(\mathrm{~m}, 2 \mathrm{H}), 7.26(\mathrm{~d}, 2 \mathrm{H}, J=8.1 \mathrm{~Hz}), 7.20(\mathrm{~m}$, 
1H), $2.44(\mathrm{~s}, 3 \mathrm{H}) .{ }^{13} \mathrm{C} \mathrm{NMR}\left(75 \mathrm{MHz}, \mathrm{CDCl}_{3}\right) \delta 157.2$, 149.3, 138.6, 136.4, 136.3, 129.2, 126.5, 121.5, 120.0, 21.0.

4.5.4. 2-(2'-Chlorophenyl)pyridine $2 f^{27,28}$ and 2 -(4'chlorophenyl)pyridine $\mathbf{2 g .}{ }^{\mathbf{2 7}}$ The general procedure (Method A) using 1a as bromide (158 mg) and chlorobenzene as solvent, gave a mixture of products $(\mathrm{o} / \mathrm{m} / \mathrm{p}$, 13:0:1). After separation by flash chromatography (silicagel, hexanes/ethyl acetate (90:10)), pure compounds $\mathbf{2 f}$ and $\mathbf{2 g}$ were obtained. Yield 84\% (148 $\mathrm{mg}$ of $\mathbf{2 f}\left(R_{\mathrm{f}}=0.35\right)$ and $11.5 \mathrm{mg}$ of $\left.\mathbf{2 g}\left(R_{\mathrm{f}}=0.45\right)\right)$. $2 \mathrm{f}$ Colorless oil; ${ }^{1} \mathrm{H}$ NMR $\left(500 \mathrm{MHz}, \mathrm{CDCl}_{3}\right) \delta 8.73(\mathrm{ddd}, 1 \mathrm{H}, J=5.0,1.7,1.1 \mathrm{~Hz})$, $7.75(\mathrm{dt}, 1 \mathrm{H}, J=8.7,1.7 \mathrm{~Hz}), 7.63(\mathrm{td}, 1 \mathrm{H}, J=7.7,1.1 \mathrm{~Hz})$, $7.57(\mathrm{~m}, 1 \mathrm{H}), 7.46(\mathrm{~m}, 1 \mathrm{H}), 7.33(\mathrm{~m}, 2 \mathrm{H}), 7.27(\mathrm{ddd}, 1 \mathrm{H}$, $J=7.7,5.0,1.1 \mathrm{~Hz}) ;{ }^{13} \mathrm{C} \mathrm{NMR}\left(75 \mathrm{MHz}, \mathrm{CDCl}_{3}\right) \delta 156.9$, $149.5,139.2,135.8,132.1,131.5,130.0,129.4,127.0$, 124.8, 122.3. 2g Colorless oil; ${ }^{1} \mathrm{H}$ NMR $\left(300 \mathrm{MHz}, \mathrm{CDCl}_{3}\right)$ $\delta 8.67(\mathrm{~d}, 1 \mathrm{H}, J=4.5 \mathrm{~Hz}), 7.93(\mathrm{~d}, 2 \mathrm{H}, J=8.6 \mathrm{~Hz}), 7.75(\mathrm{dt}$, $1 \mathrm{H}, J=7.2,1.6 \mathrm{~Hz}$ ), 7.69 (bd, $1 \mathrm{H}, J=7.2 \mathrm{~Hz}), 7.44$ (d, 2H, $J=8.6 \mathrm{~Hz}$ ), 7.24 (ddd, $1 \mathrm{H}, J=7.2,4.5,1.6 \mathrm{~Hz}$ ).

4.5.5. 2,3'-Bipyridinyl $\mathbf{3 .}^{25,30}$ The general procedure (Method A) using 1a (158 mg) as bromide and pyridine as solvent gave, after flash chromatography (silicagel, hexanes/ethyl acetate (30:70), $\left.R_{\mathrm{f}}=0.21\right) 47 \mathrm{mg}, 30 \%$ yield of bipyridine $\mathbf{3}$ as a colorless oil. Identical results were obtained from $\mathbf{1 b}(158 \mathrm{mg})$ and only traces were detected of other isomeric bipyridines. ${ }^{1} \mathrm{H}$ NMR $\left(300 \mathrm{MHz}, \mathrm{CDCl}_{3}\right) \delta$ $9.17(\mathrm{dd}, 1 \mathrm{H}, J=2.2,0.7 \mathrm{~Hz}), 8.71(\mathrm{~d}, 1 \mathrm{H}, J=4.6 \mathrm{~Hz}), 8.64$ $(\mathrm{dd}, 1 \mathrm{H}, J=4.7,1.7 \mathrm{~Hz}), 8.31(\mathrm{ddd}, 1 \mathrm{H}, J=8.2,2.2,1.7 \mathrm{~Hz})$, 7.77 (m, 2H), 7.40 (ddd, 1H, $J=8.2,4.7,0.7 \mathrm{~Hz}$ ), 7.26 (ddd, $1 \mathrm{H}, J=7.8,4.6,1.6 \mathrm{~Hz}) ;{ }^{13} \mathrm{C} \mathrm{NMR}\left(75 \mathrm{MHz}, \mathrm{CDCl}_{3}\right) \delta$ $154.8,150.1,149.9,148.2,137.1,134.4,123.7,122.9$, 120.7; MS (EI, $70 \mathrm{eV}) \mathrm{m} / \mathrm{z}$ (relative intensity) $156\left(\mathrm{M}^{+}\right.$, 100), $155\left(\mathrm{M}^{+}-1,72\right), 130$ (22), 78 (14).

\subsection{Preparation of naphthylpyridines $4 a-d$}

4.6.1. 2-Naphthalen-1-yl-pyridine $4 a^{31}$ and 2-naphthalen-2-yl-pyridine $\mathbf{4 b .}{ }^{\mathbf{3 1}}$ The general procedure (Method B) using 1a $(158 \mathrm{mg})$ as starting bromide gave, after flash chromatography, $61 \%$ yield $(\alpha / \beta 3: 1)$ of 2-naphthalenylpyridines $\mathbf{4 a}, \mathbf{b},\left(94 \mathrm{mg}\right.$ of $\mathbf{4 a}\left(R_{\mathrm{f}}=0.56\right)$ and $30 \mathrm{mg}$ of $\mathbf{4 b}$ $\left(R_{\mathrm{f}}=0.58\right)$. 4a: yellow oil; ${ }^{1} \mathrm{H}$ NMR $\left(300 \mathrm{MHz}, \mathrm{CDCl}_{3}\right) \delta$ $8.79(\mathrm{dd}, 1 \mathrm{H}, J=4.8,1.7 \mathrm{~Hz}), 8.08(\mathrm{dd}, 1 \mathrm{H}, J=7.1,2.9 \mathrm{~Hz})$, $7.91(\mathrm{~d}, 2 \mathrm{H}, J=8.1), 7.82(\mathrm{dt}, 1 \mathrm{H}, J=7.7,1.7 \mathrm{~Hz}), 7.56(\mathrm{~m}$, $5 \mathrm{H}), 7.33$ (ddd, $1 \mathrm{H}, \quad J=7.7,4.8,1.1 \mathrm{~Hz}) ;{ }^{13} \mathrm{C} \quad \mathrm{NMR}$ $\left(75 \mathrm{MHz}, \mathrm{CDCl}_{3}\right) \delta 159.5,149.7,138.7,136.5,134.2$, $131.4,129.0,128.5,127.6,126.6,126.0,125.8,125.4$, 125.2, 122.1. MS (EI, $70 \mathrm{eV}) \mathrm{m} / \mathrm{z}$ (relative intensity) 205 (M+, 39), 204 (100), 176 (9), 126 (2). 4b: yellow solid; mp $77-78{ }^{\circ} \mathrm{C}$; ${ }^{1} \mathrm{H}$ NMR $\left(300 \mathrm{MHz}, \mathrm{CDCl}_{3}\right) \delta 8.75(\mathrm{~d}, 1 \mathrm{H}$, $J=4.2 \mathrm{~Hz}), 8.49(\mathrm{~s}, 1 \mathrm{H}), 8.14(\mathrm{dd}, 1 \mathrm{H}, J=8.6,1.5 \mathrm{~Hz}), 7.90$ $(\mathrm{m}, 4 \mathrm{H}), 7.80(\mathrm{td}, 1 \mathrm{H}, J=7.5,1.8 \mathrm{~Hz}), 7.50(\mathrm{~m}, 2 \mathrm{H}), 7.26$ $(\mathrm{dd}, 1 \mathrm{H}, J=7.5,4.2 \mathrm{~Hz}) ;{ }^{13} \mathrm{C} \mathrm{NMR}\left(75 \mathrm{MHz}, \mathrm{CDCl}_{3}\right) \delta$ $157.3,149.7,136.7,133.5,133.4,128.6,128.3,127.6$, $126.4,126.2,124.5,122.1,120.7$; MS (EI, $70 \mathrm{eV}) \mathrm{m} / \mathrm{z}$ (relative intensity) $205\left(\mathrm{M}^{+}, 100\right), 204$ (66), 176 (16), 126 (8).

4.6.2. 3-Naphthalen-1-yl-pyridine $4 c^{32}$ and 3-naphthalen-2-yl-pyridine 4d. ${ }^{31}$ The general procedure (Method B) using $\mathbf{1 b}(158 \mathrm{mg})$ as starting bromide gave, after flash chromatography $50 \%(\alpha / \beta 5: 1)$ of 3-Naphthalenyl-pyridines $\mathbf{4 c}, \mathbf{d},\left(85.5 \mathrm{mg}\right.$ of $\mathbf{4 c}\left(R_{\mathrm{f}}=0.35\right)$ and $17 \mathrm{mg}$ of $\mathbf{4 d}$ $\left(R_{\mathrm{f}}=0.23\right)$. 4c: colorless oil; ${ }^{1} \mathrm{H}$ NMR $\left(300 \mathrm{MHz}, \mathrm{CDCl}_{3}\right) \delta$ $8.76(\mathrm{~d}, 1 \mathrm{H}, J=2.2 \mathrm{~Hz}), 8.67(\mathrm{dd}, 1 \mathrm{H}, J=4.9,1.6 \mathrm{~Hz}), 7.92$ $(\mathrm{m}, 2 \mathrm{H}), 7.82(\mathrm{~m}, 2 \mathrm{H}), 7.54(\mathrm{~m}, 5 \mathrm{H}) ;{ }^{13} \mathrm{C} \mathrm{NMR}(75 \mathrm{MHz}$, $\left.\mathrm{CDCl}_{3}\right) \delta 150.5,148.4,137.4,136.2,133.8,131.5,128.5$, 128.4, 127.4, 126.5, 126.1, 125.3, 125.2, 123.1; HPLC-MS (CI) $\left[\mathrm{M}^{+}+1\right]=206.1$. 4d: white solid, mp $101-103{ }^{\circ} \mathrm{C} ;{ }^{1} \mathrm{H}$ NMR $\left(300 \mathrm{MHz}, \mathrm{CDCl}_{3}\right) \delta 8.96(\mathrm{~d}, 1 \mathrm{H}, J=1.6 \mathrm{~Hz}), 8.60$ (dd, $1 \mathrm{H}, J=4.8,1.6 \mathrm{~Hz}), 8.06(\mathrm{~s}, 1 \mathrm{H}), 8.03(\mathrm{td}, 1 \mathrm{H}, J=8.1$, $1.6 \mathrm{~Hz}), 7.90(\mathrm{~m}, 3 \mathrm{H}), 7.71(\mathrm{dd}, 1 \mathrm{H}, J=8.5,2.0 \mathrm{~Hz}), 7.53$ $(\mathrm{m}, 2 \mathrm{H}), 7.40(\mathrm{dd}, 1 \mathrm{H}, J=8.1,4.8 \mathrm{~Hz}) ;{ }^{13} \mathrm{C} \mathrm{NMR}(75 \mathrm{MHz}$, $\left.\mathrm{CDCl}_{3}\right) \delta 148.5,148.4,135.0,134.5,133.5,132.8,128.8$. 128.1, 127.6, 126.5, 126.3, 126.1, 124.9, 123.5; MS (CI, $70 \mathrm{eV}) \mathrm{m} / \mathrm{z}$ (relative intensity) $206\left(\mathrm{M}^{+}+1,100\right), 159$ (5).

\subsection{Preparation of biphenyl compounds $6 a-c$ and arylpyridines 7-9}

4.7.1. 4-Methylbiphenyl $6 a^{33,34}$ The general procedure (Method A) using 5a as bromide (171 mg) and benzene as solvent gave, after flash chromatography (silicagel, hexanes/ethyl acetate (95:5)), a white solid, mp $46-47^{\circ} \mathrm{C}$ (85.5 mg, 51\%). ${ }^{1} \mathrm{H}$ NMR (500 MHz, CD 3 OD) $\delta 7.59$ (dd, $2 \mathrm{H}, J=8.3,1.2 \mathrm{~Hz}), 7.50(\mathrm{~d}, 2 \mathrm{H}, J=8.1 \mathrm{~Hz}), 7.42(\mathrm{t}, 2 \mathrm{H}$, $J=8.3 \mathrm{~Hz}), 7.31(\mathrm{td}, 1 \mathrm{H}, J=8.3,1.2 \mathrm{~Hz}) 7.25(\mathrm{~d}, 2 \mathrm{H}$, $J=8.1 \mathrm{~Hz}), 2.39(\mathrm{~s}, 3 \mathrm{H}) ;{ }^{13} \mathrm{C} \mathrm{NMR}\left(125 \mathrm{MHz}, \mathrm{CD}_{3} \mathrm{OD}\right) \delta$ 142.4, 139.6, 138.1, 130.4, 129.7, 127.9, 127.8, 127.7, 21.1.

4.7.2. 4-Methoxybiphenyl $6 b^{33,35}$ The general procedure (Method A) using 5b as bromide (187 $\mathrm{mg}$ ) and benzene as solvent gave, after flash chromatography (silicagel, hexanes/ethyl acetate (95:5)), a white solid, mp $86-87^{\circ} \mathrm{C}$ (92 mg, 50\%); ${ }^{1} \mathrm{H}$ NMR (300 MHz, $\left.\mathrm{CDCl}_{3}\right) \delta 7.56$ (m, 4H), $7.43(\mathrm{t}, 2 \mathrm{H}, J=7.5 \mathrm{~Hz}), 7.32(\mathrm{tt}, 1 \mathrm{H}, J=7.5,1.2 \mathrm{~Hz}) 6.99$ (d, $2 \mathrm{H}, J=8.8 \mathrm{~Hz}), 3.86(\mathrm{~s}, 3 \mathrm{H}) ;{ }^{13} \mathrm{C} \mathrm{NMR}\left(75 \mathrm{MHz}, \mathrm{CDCl}_{3}\right) \delta$ 159.1, 140.8, 133.7, 128.7, 128.1, 126.7, 126.6, 114.1, 55.3.

4.7.3. Biphenyl 4-carboxylic acid methyl ester $6 c .{ }^{34,36}$ The general procedure (Method A) using $\mathbf{5 c}$ as bromide (215 mg) and benzene as solvent gave, after flash chromatography (silicagel, hexanes/ethyl acetate (95:5)), a white solid, mp $116-117^{\circ} \mathrm{C}(110 \mathrm{mg}, 52 \%) .{ }^{1} \mathrm{H}$ NMR (300 MHz, $\left.\mathrm{CDCl}_{3}\right) \delta 8.04(\mathrm{~d}, 2 \mathrm{H}, J=8.4 \mathrm{~Hz}), 7.59(\mathrm{~d}, 2 \mathrm{H}, J=8.4 \mathrm{~Hz})$, $7.56(\mathrm{dd}, 2 \mathrm{H}, J=7.4,1.3 \mathrm{~Hz}) ; 7.44(\mathrm{dd}, 2 \mathrm{H}, J=7.4,7.2 \mathrm{~Hz})$, $7.33(\mathrm{tt}, 1 \mathrm{H}, J=7.2,1.3 \mathrm{~Hz}) 3.89(\mathrm{~s}, 3 \mathrm{H}) ;{ }^{13} \mathrm{C} \mathrm{NMR}$ $\left(75 \mathrm{MHz}, \mathrm{CDCl}_{3}\right) \delta 166.9,145.5,139.9,130.0,128.8$, 128.6, 128.1, 127.2, 126.9, 52.0.

4.7.4. 2-(4'-Methylphenyl)pyridine $2 \mathrm{e}^{11 \mathrm{a}, 27,29}$ and $3-\left(4^{\prime}-\right.$ methylphenyl)pyridine $\mathbf{7 . 1 1}^{11}$ The general procedure (Method A) using 5a (171 mg) as starting bromide and pyridine as solvent did not generate any biaryl compound. The same process, using Method $\mathrm{C}$ gave, after separation by flash chromatography (silicagel, hexanes/ethyl acetate (80:20)), $10 \%$ yield of $4^{\prime}$-methylphenyl)pyridines $(\alpha / \beta / \gamma$ $4: 1: 0)$. 2e $\left(13.5 \mathrm{mg}, R_{\mathrm{f}}=0.80\right)$ colorless oil; ${ }^{1} \mathrm{H}$ NMR $\left(300 \mathrm{MHz}, \mathrm{CDCl}_{3}\right) \delta 8.67(\mathrm{~d}, 1 \mathrm{H}, J=4.4 \mathrm{~Hz}), 7.86(\mathrm{~d}, 2 \mathrm{H}$, $J=8.1 \mathrm{~Hz}), 7.70(\mathrm{~m}, 2 \mathrm{H}), 7.26(\mathrm{~d}, 2 \mathrm{H}, J=8.1 \mathrm{~Hz}), 7.20(\mathrm{~m}$, 1H), $2.44(\mathrm{~s}, 3 \mathrm{H}) ;{ }^{13} \mathrm{C} \mathrm{NMR}\left(75 \mathrm{MHz}, \mathrm{CDCl}_{3}\right) \delta 157.2$, 149.3, 138.6, 136.4, 136.3, 129.2, 126.5, 121.5, 120.0, 21.0; MS (EI, $70 \mathrm{eV}) \mathrm{m} / \mathrm{z}$ (relative intensity) $169\left(\mathrm{M}^{+}, 100\right), 168$ $\left(59, \mathrm{M}^{+}+1\right), 154(9), 51(20) .7\left(4 \mathrm{mg}, R_{\mathrm{f}}=0.53\right)$ colorless 
oil; ${ }^{1} \mathrm{H}$ NMR $\left(300 \mathrm{MHz}, \mathrm{CDCl}_{3}\right) \delta 8.82(\mathrm{~d}, 1 \mathrm{H}, J=2.3 \mathrm{~Hz})$, 8.55 (dd, $1 \mathrm{H}, J=4.6,1.5 \mathrm{~Hz}), 7.85$ (ddd, $1 \mathrm{H}, J=7.81,2.3$, $1.5 \mathrm{~Hz}), 7.48(\mathrm{~d}, 2 \mathrm{H}, J=8.2 \mathrm{~Hz}), 7.35(\mathrm{~m}, 1 \mathrm{H}), 7.30(\mathrm{~d}, 2 \mathrm{H}$, $J=8.2 \mathrm{~Hz}$ ), $2.42(\mathrm{~s}, 3 \mathrm{H})$; MS (EI, $70 \mathrm{eV}$ ) $\mathrm{m} / \mathrm{z}$ (relative intensity) $169\left(\mathrm{M}^{+}, 83\right), 110$ (100), 80 (30).

4.7.5. 2-(4'-Methoxyphenyl)pyridine $8 a^{\prime},{ }^{11 a, 27} 3-\left(4^{\prime}-\right.$ methoxyphenyl)pyridine $8 b^{11 a}$ and $4-\left(4^{\prime}\right.$-methoxyphenyl)pyridine $\mathbf{8 c} .{ }^{37}$ The general procedure (Method A) using 5b (187 mg) as starting bromide and pyridine as solvent gave, after separation by flash chromatography (silicagel, hexanes/ethyl acetate $(70: 30)), 30 \%$ yield of methoxyphenylpyridines $8 \mathbf{a}-\mathbf{c}(\alpha / \beta / \gamma \quad 4: 1: 1)$. The same process, using Method $\mathrm{C}$ gave $72 \%$ yield of methoxyphenylpyridines $\mathbf{8 a}-\mathbf{c}(\alpha / \beta / \gamma \quad 10: 1: 4)$. 8a (37 mg from Method A or $92.5 \mathrm{mg}$ from Method B) $\left(R_{\mathrm{f}}=0.80\right)$ colorless plates, mp 53-54 ${ }^{\circ} \mathrm{C} ;{ }^{1} \mathrm{H}$ NMR $\left(300 \mathrm{MHz}, \mathrm{CDCl}_{3}\right) \delta 8.65$ $(\mathrm{dd}, 1 \mathrm{H}, J=4.7,1.8 \mathrm{~Hz}), 7.95(\mathrm{~d}, 2 \mathrm{H}, J=7.9 \mathrm{~Hz}), 7.72(\mathrm{ddd}$, $1 \mathrm{H}, J=8.0,6.9,1.8 \mathrm{~Hz}$ ), 7.66 (dd, $1 \mathrm{H}, J=8.0,1.5 \mathrm{~Hz}), 7.16$ (ddd, 1H, J=6.9, 4.7, $1.5 \mathrm{~Hz}), 6.98$ (d, 2H, J=7.9 Hz), 3.90 $(\mathrm{s}, 3 \mathrm{H}) ;{ }^{13} \mathrm{C} \mathrm{NMR}\left(75 \mathrm{MHz}, \mathrm{CDCl}_{3}\right) \delta 160.3,156.9,149.3$, 136.7, 131.7, 128.1, 121.3, 119.9, 114.0, 55.3; MS (EI, $70 \mathrm{eV}) \mathrm{m} / \mathrm{z}$ (relative intensity) $185\left(\mathrm{M}^{+}, 100\right), 170(36), 142$ (45), 141 (31), 84 (14). 8b (9 mg from Method A or 9 mg from Method C) $\left(R_{\mathrm{f}}=0.35\right)$ colorless plates, mp $63-64{ }^{\circ} \mathrm{C}$; ${ }^{1} \mathrm{H} \mathrm{NMR}\left(300 \mathrm{MHz}, \mathrm{CDCl}_{3}\right) \delta 8.80(\mathrm{~d}, 1 \mathrm{H}, J=1.8 \mathrm{~Hz}), 8.53$ (dd, $1 \mathrm{H}, J=4.7,1.4 \mathrm{~Hz}$ ), 7.83 (ddd, $1 \mathrm{H}, J=8.1,1.8,1.4 \mathrm{~Hz}$ ), 7.51 (d, 2H, $J=8.8 \mathrm{~Hz}), 7.33$ (ddd, $1 \mathrm{H}, J=8.1,4.7,0.7 \mathrm{~Hz}$ ), $7.01(\mathrm{~d}, 2 \mathrm{H}, J=8.8 \mathrm{~Hz}), 3.80(\mathrm{~s}, 3 \mathrm{H}) ;{ }^{13} \mathrm{C} \mathrm{NMR}(75 \mathrm{MHz}$, $\left.\mathrm{CDCl}_{3}\right) \delta 159.8,148.0,147.9,136.2,133.8,130.2,128.2$, 123.4, 114.5, 55.3; MS (EI, $70 \mathrm{eV}) \mathrm{m} / \mathrm{z}$ (relative intensity) $185\left(\mathrm{M}^{+}, 100\right), 170$ (54), 142 (52), 115 (30). 8c (9 mg from Method A or $30 \mathrm{mg}$ from Method C) $\left(R_{\mathrm{f}}=0.22\right)$, white solid, mp 95-96 ${ }^{\circ} \mathrm{C} ;{ }^{1} \mathrm{H}$ NMR $\left(300 \mathrm{MHz}, \mathrm{CDCl}_{3}\right) \delta 8.60(\mathrm{dd}, 2 \mathrm{H}$, $J=4.6,1.6 \mathrm{~Hz}), 7.60(\mathrm{~d}, 2 \mathrm{H}, J=9 \mathrm{~Hz}), 7.51(\mathrm{dd}, 2 \mathrm{H}, J=4.6$, $1.6 \mathrm{~Hz}), 7.01(\mathrm{~d}, 2 \mathrm{H}, J=9 \mathrm{~Hz}), 3.85(\mathrm{~s}, 3 \mathrm{H}) ;{ }^{13} \mathrm{C} \mathrm{NMR}$ $\left(75 \mathrm{MHz}, \mathrm{CDCl}_{3}\right) \delta 160.8,150.3,148.1,130.5,128.3$, 121.3, 114.8, 55.6; MS (EI, $70 \mathrm{eV}) \mathrm{m} / \mathrm{z}$ (relative intensity) $185\left(\mathrm{M}^{+}, 100\right), 170$ (34), 142 (42), 115 (32), 86 (51), 84 (75).

4.7.6. 4-Pyridin-2-yl-benzoic acid methyl ester $9 \mathrm{a},{ }^{11 a, 27}$ 4-pyridin-3-yl-benzoic acid methyl ester 9b ${ }^{11 a}$ and 4-pyridin-4-yl-benzoic acid methyl ester 9c. ${ }^{38}$ The general procedure (Method A) using $\mathbf{5 c}(215 \mathrm{mg})$ as starting bromide and pyridine as solvent gave, after separation by flash chromatography (silicagel, hexanes/ethyl acetate (70:30)), $15 \%$ yield of $9 \mathbf{a}, \mathbf{b}(\alpha / \beta / \gamma \quad 2: 1: 0)$. The same process, using Method B gave $20 \%$ yield of 4-pyridin benzoic acid methyl esters 9a-c $(\alpha / \beta / \gamma 2: 1: 0.1)$. 9a (21 mg from Method A or $29 \mathrm{mg}$ from Method C) $\left(R_{\mathrm{f}}=0.60\right)$ colorless plates, mp $97-98{ }^{\circ} \mathrm{C}$; ${ }^{1} \mathrm{H} \mathrm{NMR}\left(300 \mathrm{MHz}, \mathrm{CDCl}_{3}\right)$ $\delta 8.71(\mathrm{dd}, 1 \mathrm{H}, J=4.7,1.3 \mathrm{~Hz}), 8.13(\mathrm{~d}, 2 \mathrm{H}, J=8.7 \mathrm{~Hz}), 8.11$ (d, 2H, J=8.7 Hz), $7.77(\mathrm{~m}, 2 \mathrm{H}), 7.27(\mathrm{dd}, 1 \mathrm{H}, J=8.9$, $4.7 \mathrm{~Hz}), 3.90(\mathrm{~s}, 3 \mathrm{H}) ;{ }^{13} \mathrm{C} \mathrm{NMR}\left(75 \mathrm{MHz}, \mathrm{CDCl}_{3}\right) \delta 166.8$, $156.1,149.8,143.4,136.9,130.3,129.9,126.7,122.8$, 120.9, 52.1; MS (EI, $70 \mathrm{eV}) \mathrm{m} / \mathrm{z}$ (relative intensity) 213 $\left(\mathrm{M}^{+}, 58\right), 182$ (100), 154 (47), 127 (24). 9b (11 mg from Method A or $15 \mathrm{mg}$ from Method C) $\left(R_{\mathrm{f}}=0.40\right)$, white solid, mp 105-107 ${ }^{\circ} \mathrm{C} ;{ }^{1} \mathrm{H}$ NMR $\left(300 \mathrm{MHz}, \mathrm{CDCl}_{3}\right) \delta 8.87(\mathrm{~d}, 1 \mathrm{H}$, $J=1.7 \mathrm{~Hz}), 8.63(\mathrm{dd}, 1 \mathrm{H}, J=4.8,1.7 \mathrm{~Hz}), 8.14(\mathrm{~d}, 2 \mathrm{H}$, $J=8.4 \mathrm{~Hz}), 7.91(\mathrm{td}, 1 \mathrm{H}, J=7.8,1.7 \mathrm{~Hz}), 7.65(\mathrm{~d}, 2 \mathrm{H}$, $J=8.4 \mathrm{~Hz}), 7.40(\mathrm{dd}, 1 \mathrm{H}, J=7.8,4.8 \mathrm{~Hz}), 3.94(\mathrm{~s}, 3 \mathrm{H}) ;{ }^{13} \mathrm{C}$ NMR (75 MHz, $\left.\mathrm{CDCl}_{3}\right) \delta 166.6,149.1,148.2,142.1,135.5$,
134.4, 130.3, 129.7, 127.0, 123.6, 52.1; MS (EI, $70 \mathrm{eV}) \mathrm{m} / \mathrm{z}$ (relative intensity) $213\left(\mathrm{M}^{+}, 68\right), 182$ (100), 154 (27), 127 (21).

9c ( $1 \mathrm{mg}$ from Method C) $\left(R_{\mathrm{f}}=0.15\right)$ white solid, mp $103-$ $105{ }^{\circ} \mathrm{C} ;{ }^{1} \mathrm{H}$ NMR $\left(300 \mathrm{MHz}, \mathrm{CDCl}_{3}\right) \delta 8.70(\mathrm{~d}, 2 \mathrm{H}$, $J=4.2 \mathrm{~Hz}), 8.15$ (d, 2H, $J=8.4 \mathrm{~Hz}, 7.70 \quad(\mathrm{~d}, 2 \mathrm{H}$, $J=8.4 \mathrm{~Hz}$ ), 7.54 (d, 2H, $J=4.2 \mathrm{~Hz}$ ), 3.94 (s, 3H); MS (EI, $70 \mathrm{eV}) \mathrm{m} / z$ (relative intensity) $213\left(\mathrm{M}^{+}, 95\right), 182$ (100), 154 (56), 127 (66), 80 (48).

\section{Acknowledgements}

Financial support by the Comision Interministerial de Ciencia y Tecnología (CICYT, project BQU2001-1508) and a grant to one of us by the Universidad de Alcalá (A.N) are gratefully acknowledged.

\section{References and notes}

1. Stanforth, S. P. Tetrahedron 1998, 54, 263-303.

2. Tour, J. M. Acc. Chem. Res. 2000, 33, 791-804.

3. García-Cuadrado, D.; Cuadro, A. M.; Alvarez-Builla, J.; Vaquero, J. J. Synlett 2002, 1904-1906.

4. Suzuki, A. J. Organomet. Chem. 1999, 576, 147-168.

5. Narasimhan, N.; Aidhen, I. S. Tetrahedron Lett. 1988, 29, 2987-2988.

6. (a) Tsuge, O.; Hatta, T.; Tsuchiyam, H. Chem. Lett. 1998, 155-156. (b) Escolano, C.; Jones, K. Tetrahedron 2002, 58, 1453-1464, and references cited therein.

7. (a) Lucilia, M.; da Mata, E. N.; Motherwell, W. B.; Ujjainwalla, F. Tetrahedron Lett. 1997, 38, 137-140. (b) Lucilia, M.; da Mata, E. N.; Motherwell, W. B.; Ujjainwalla, F. Tetrahedron Lett. 1997, 38, 141-144. (c) Ryokawa, A.; Togo, H. Tetrahedron 2001, 57, 5915-5921.

8. (a) Clive, D. L.; Kang, S. Tetrahedron Lett. 2000, 41, 1315-1319. (b) Clive, D. L.; Kang, S. J. Org. Chem. 2001, 66, 6083-6091.

9. Studer, A.; Bossart, M.; Vasella, T. Org. Lett. 2000, 2, 985-988.

10. Harrowven, D.; Nunn, M. I. T.; Newman, N. A.; Fenwick, D. R. Tetrahedron Lett. 2001, 42, 961-964.

11. (a) Ohkura, K.; Terashima, M.; Kanaoka, Y.; Seki, K. Chem. Pharm. Bull. 1993, 41, 1920-1924. (b) Ohkura, K.; Seki, K.; Terashima, M.; Kanaoka, Y. Tetrahedron Lett. 1989, 30, 3433-3436. (c) Park, Y. T.; Jung, C. H.; Kim, M. S.; Kim, K. W. J. Org. Chem. 2001, 66, 2197-2206, and references cited herein.

12. Martínez-Barrasa, V.; García de Viedma, A.; Burgos, C.; Alvarez-Builla, J. Org. Lett. 2000, 2, 3933-3935.

13. Crich, D.; Sannigrahi, M. Tetrahedron 2002, 58, 3319-3322.

14. Fleming, I. Frontier Orbitals and Organic Chemical Reactions; Wiley: Chichester, 1976; pp. 182-194.

15. Dickerman, S.; Vermont, G. B. J. Am. Chem. Soc. 1962, 84, 4150-4151.

16. Dobbs, A.; Jones, K.; Veal, K. T. Tetrahedron 1998, 54, 2149-2160.

17. Jones, K.; Dobbs, A.; Veal, K. T. Tetrahedron Lett. 1995, 36, 4857-4860. 
18. Renaud, P.; Sibi, M. P. Radicals in Organic Synthesis; WileyVCH: Weinheim, 2001; Vol. 2. pp. 63-80.

19. Fossey, J.; Lefort, D.; Sorba, J. Free Radicals in Organic Chemistry; Wiley: Chichester, 1995; pp. 166-180.

20. Minisci, F.; Vismara, E.; Fontana, F.; Morini, G.; Serravalle, M. J. Org. Chem. 1986, 51, 4411-4416.

21. Minisci, F.; Fontana, F.; Vismara, E. J. Heterocyclic Chem. 1990, 27, 79-96.

22. Minisci, F.; Fontana, F.; Pianese, G.; Yan, Y. M. J. Org. Chem. 1993, 58, 4207-4221.

23. Togo, H.; Hayashi, K.; Yokoyama, M. Chem. Lett. 1991, 1064-2063.

24. Togo, H.; Hayashi, K.; Yokoyama, M. Chem. Lett. 1993, 641-644.

25. Sakamoto, T.; Kondo, Y.; Murata, N.; Yamanaka, H. Tetrahedron 1993, 49, 9713-9720.

26. Ali, N.; Mckillop, A.; Mitchell, M. B.; Rebelo, R. A.; Wallbank, P. J. Tetrahedron 1992, 48, 8117-8126.

27. Terashima, M.; Yoshida, C.; Ohkura, K.; Kanaoka, Y. Chem. Pharm. Bull. 1985, 33, 1009-1015.

28. Butler, D.; Bass, P.; Nordin, I. G.; Havak, F. P.; L'Italien, Y. J. J. Med. Chem. 1971, 14, 575-579.
29. Gosmini, C.; Lasry, S.; Nedelec, Y.; Perichon, J. Tetrahedron 1998, 54, 1289-1298.

30. Ishikura, M.; Kamada, M.; Terashima, M. Synthesis 1984, 936-938.

31. Chattergea, J. N.; Shaw, S. C.; Prasad, Y.; Singh, R. P. J. Indian Chem. Soc. 1984, 61, 1028-1031.

32. Katoh, T.; Ogawa, K.; Inagaki, Y. Tetrahedron 1997, 53, 3557-3570.

33. Mowery, M. E.; DeShong, P. J. Org. Chem. 1999, 64, 3266-3270.

34. Old, D.; Wolfe, P.; Buchwald, S. L. J. Am. Chem. Soc. 1998, 120, 9722-9723.

35. Lipshutz, B.; Siegmann, K.; García, E.; Kayser, F. J. Am. Chem. Soc. 1993, 115, 9276-9282.

36. Barba, I.; Chinchilla, R.; Gómez, C. Tetrahedron 1990, 46, 7813-7822.

37. Katritzky, A.; Beltrami, H.; Sammes, M. P. J. Chem. Soc. Perkin Trans. 1 1980, 2480-2484.

38. Matsushita, Y.; Sakamoto, K.; Murakami, T.; Matsui, T. Synth. Commun. 1994, 24, 3307-3313. 